\title{
Student Experience in Completing Thesis and its Implications for International Students in Indonesia
}

\author{
Ermiati Ermiati ${ }^{1 \star}$, Restuning Widiasih ${ }^{1}$, Yayat Suryati ${ }^{2}$, Murtiningsih Murtiningsih $^{2}$ \\ ${ }^{1}$ Department of Maternity Nursing, Faculty of Nursing, Universitas Padjadjaran, Bandung, Indonesia; ${ }^{2}$ Department of Nursing, \\ Sekolah Tinggi IImu Kesehatan Jendral Achmad Yani, Bandung, Indonesia
}

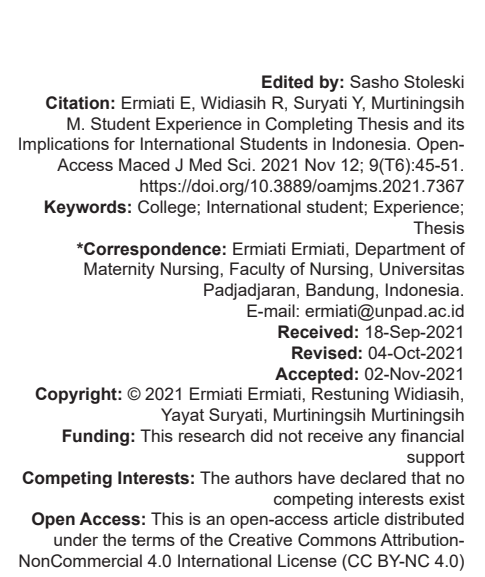

Abstract AIM: This study aims to explore student experiences in completing thesis courses and analyze the implications of
these courses for international students.

METHODS: This phenomenological research interviewed 18 students who had completed the thesis course. Data were collected through in-depth interviews to explore the experience of participants in completing the thesis. Data analysis was carried out using the Colaizzi method.

RESULTS: We found three main themes and nine subthemes. The main themes include positive and negative support systems during the thesis, physical and psychological problems experienced by students during the thesis and learning and expectations in the thesis course.

CONCLUSION: The thesis has the potential for scientific development, impacts on students, and psychological and suicidal ideation. Integrated mentoring services: Academic and mental will be useful to prevent and overcome problems faced by Indonesian students and international students.

\section{Introduction}

The thesis process includes a series of activities starting from the proposed research topic, evaluating the research proposal, submitting research ethics approval, collecting data, analyzing data, writing the final report, final examination, and publication of the work made. Thus, thesis writing has several objectives for students, namely, being able to write scientific papers in the scientific area being studied, being able to conduct research that can be accounted for in terms of content and research processes, and finally, the knowledge learned can be applied according to their scientific field [1]. Therefore, it can be said that the thesis process is complex because students are expected to be able to combine their knowledge and skills in understanding, analyzing, describing, and explaining problems related to the scientific field that is their focus.

While working on the thesis, students are required to work individually and independently [2]. In the process of working on a thesis, students often encounter obstacles. Difficulties in completing the thesis are divided into internal and external problems [3]. Internal challenges include laziness, low motivation, fear of meeting lecturers, and difficulty adjusting to supervisors. External challenges have difficulty adjusting time with supervisors, lack of guidance time, difficulty finding themes, repeated revisions, length of feedback from lecturers, parental demands to graduate immediately, financial problems, work, and age. These obstacles can have an impact on student welfare or even increase the risk of health problems.

The burdens and problems experienced by students during the thesis process can be felt like a heavy burden and can result in negative feelings. These negative feelings can develop into low self-esteem, frustration, loss of motivation, and stress [4]. Research on 221 students working on a thesis at Universitas Airlangga shows that students are identified as experiencing stress with varying levels. The analysis results showed that $25.8 \%$ of students experienced severe anxiety, followed by everyday stress $23.1 \%$, very severe stress $22.6 \%$, moderate stress $15.8 \%$, and mild stress $12.7 \%$ [5]. In addition to quantitative research, qualitative research on anxiety in nine medical students who underwent a final project using the Focus Group Discussion method found that students experienced anxiety when determining the research background and other stages of the thesis 
writing process [6]. If this stressful condition continues, students are at risk of experiencing despair. When a person feels hopeless, he can take shortcuts to commit suicide [7]. A survey conducted at a teaching hospital in Bandung found that $30.5 \%$ of students were depressed, $20 \%$ thought about suicide, and $6 \%$ attempted suicide [8]. At the end of 2018, there were suicides by three students who were working on their thesis at a university in Bandung. This is evidence of the high suicide rate among students who are working on their thesis [9]. The thesis is one of the predisposing factors for mental problems at the university.

The mental problems experienced by students have been investigated using both quantitative and qualitative methods. Mental problems during the education process in universities that are widely studied are anxiety [10], [11], [12], anxiety coping interventions [13], and some surveys about the impact of thesis [8], [9]. International students also experience mental problems, namely, more stress and difficulty in adapting culturally [14], [15], social and language difficulties [16], easily emotional, have trouble sleeping, and eating disorders [17].

These studies were conducted with different situations, focusing on anxiety problems and how to overcome them. On the other hand, there is a possibility that students' psychological problems are limited to anxiety. The limitation experience among students during the final project or thesis comes from various aspects such as students personality, facilities, and expectations. Exploration of experience will be able to dig deeper and wider about the problems experienced that may threaten the welfare of students physically and psychologically both for Indonesian students and international students studying in Indonesia. International students studying in Indonesia will follow the same educational process and learning system as Indonesian students. This study aims were to explore the student experiences in completing thesis courses and analyzes the implications of these courses for international students at two different universities.

\section{Methods}

This research was qualitative research that is collecting, interpreting, and finding the meaning of a phenomenon through individual or group interviews, and observation. This study uses a phenomenological approach, which aims to reduce personal experience into the common meaning of a phenomenon experienced by a group of individuals [18]. This study focuses on exploring the experiences of Indonesian students in completing thesis courses and then analyzing its implications for international students.

\section{Participants and settings}

The participants in this study were students from two nursing education institutions located in West Java, namely, the Faculty of Nursing, Universitas Padjadjaran, and the College of Health Sciences Achmad Yani. Participants in this study were recruited through announcements in the nurse's profession WhatsApp group, and students who were interested in becoming participants contacted the researchers through the main researcher's cell phone number. The criteria for the participants are nursing students who have completed the thesis a maximum of 1 year ago and are currently participating in the Nursing profession program. The number of participants in this study was 18 students.

\section{Data collection}

Data were collected through in-depth interviews to explore the experience of participants in completing the thesis. The interview technique was conducted to explore the participants' experiences while completing the thesis. Interviews were conducted by four researchers who had previously conducted perceptual equations and interview exercises, with semi-structured question guidelines. Before the interview was conducted, participants have explained again about the purpose of the study, the data collection process, and the role of the participants. Then, the willing participants were asked to sign the consent form. Each participant was interviewed separately with a period of 20-45 min, and during the interview, recording was done. The questions include three main questions: (1) How was the experience while completing the thesis? (2) What are the physical and psychological changes experienced during the completion of the thesis? and (3) What are the future expectations for thesis courses? Data collection was carried out by taking into account the ethical principles of research, such as maintaining privacy in the interview process, researchers respecting the rights of participants, participation in this study is voluntary, and participants can refuse to answer if they are not pleased with the questions given.

\section{Data analysis}

The first stage in the data analysis process is to do a verbatim transcript. The next step is to analyze the data with seven stages of the Colaizzi method, 1978 [19]. The first step by understanding the contents of each transcript. It can be conducted by listening the recording and reading the transcript at least 5-8 times. The second stage is marking or coding important words, sentences, or expressions from the participants related to the experience when completing the thesis. The coding results are stored in one file and given the name of the participant (file 1). The third stage is to formulate units, namely, words, sentences, and 
expressions grouped based on the same idea from various participants (file 2 ). The fourth stage is to read the two files and group them in the same theme and merge them into the main theme. The fifth stage is to integrate all the results into a comprehensive theme. At this stage, the researcher determines the main theme supported by data files 1 and 2 and discusses the theme with the research team. The sixth stage is to write in full the themes found, integrated with participant experience data. Finally, the seventh stage validates the results of the analysis by returning to the participants to explain the results of the sixth stage and to ensure that the results of the analysis are following the experiences of students. Based on the analysis, three main themes and nine subthemes were found.

\section{Trustworthiness}

In this study, the trustworthiness was conducted by credibility, dependability, confirmability, and authenticity [18]. Credibility means that the researcher verifies back to the informant to ensure the accuracy of the data in the interview. Transferability in qualitative research is not generalized so that the researcher writes in a clear, detailed, systematic, and reliable way by writing quotes and comments. Reliability is carried out by conducting data investigations where verification, data reduction results, and recording of the research process are carried out. Confirmation is done by systematically recording raw data, including field notes.

\section{Results}

Participants in this study amounted to 18 students with characteristics (Table 1). Participants are labeled P1 to P18. The label will be written as a marker of the opinion of the participants quoted on the results of the study. Most students complete the thesis for 6-8 months, and there is one student who takes 18 months to complete the thesis. Participants are aged 22-23 years old and are currently studying in the $1^{\text {st }}$ semester of the nursing profession program.

The themes found based on data analysis are summarized in Table 2.

\section{Theme 1: Positive and negative support system during thesis}

Participants from public or private universities said that during the thesis process, they received various positive supports, but on the other hand, they experienced many negative things. Students' positive and negative support systems during their thesis are obtained from friends, supervisors, and parents.
Table 1: Participants characteristics $(n=18)$

\begin{tabular}{lll}
\hline Participants & Age & Time to completing thesis \\
\hline P1 & 22 & 7 months \\
P2 & 22 & 6 months \\
P3 & 22 & 7 months \\
P4 & 22 & 8 months \\
P5 & 23 & 8 months \\
P6 & 23 & 8 months \\
P7 & 22 & 8 months \\
P8 & 22 & 8 months \\
P9 & 22 & 8 months \\
P10 & 23 & 18 months \\
P11 & 22 & 6 months \\
P12 & 22 & 6 months \\
P13 & 22 & 6 months \\
P14 & 22 & 6 months \\
P15 & 22 & 6 months \\
P16 & 22 & 6 months \\
P17 & 22 & 6 months \\
P18 & 22 & 6 months \\
\hline
\end{tabular}

\section{Support and lost friends}

During the process of completing the thesis, friends became a support system that greatly influenced the participants. According to the participants, friends help in various things during the thesis process. Friends act as motivators, partners/teams, and friends in discussions.

Yes, my friend, so if it's difficult, make it something that has been finished, right... oh, this is the difficulty, look for the gap, Mrs. So... I like to ask for help finding the gap, keep giving input, it should be like this and this, then..., this journal is a bit inappropriate or something (P8).

Support was also expressed by other participants, such as being assisted when making proposals, collecting data, making reports, accompanying each advisory consul, going together to campus to meet supervisors, venting, and crying when feeling sad, stressed, or failing and getting together when they are finished - tired of looking for a pleasant atmosphere before returning to writing the thesis (P3, P4, P7, P11, P12, P17, and P18).

Table 2: Thesis student experience theme

\begin{tabular}{ll}
\hline Themes & Categories \\
\hline Positive and negative support & - Support and lost friends \\
system during thesis & - Supervisor capacity \\
& - Support and pressure from parent \\
Physical and psychological & - Physical problems lead to psychosomatic \\
problems experienced during the & symptoms and infectious diseases \\
thesis process & - Physical problems related to immunity and allergic \\
& diseases \\
& - Unstable emotions \\
& - Desire to commit suicide \\
Learning and expectations for & - Positive self-efficacy \\
thesis courses & - Lack of facilities and improvement of the guidance \\
& system \\
\hline
\end{tabular}

On the other hand, the thesis process also causes the loss of friends. This happens because of differences in the progress of completing the thesis. Feeling that you have lost a friend because a group of friends completed the thesis first (P10). Participants who had completed their thesis earlier than their friends in the group also revealed feeling shunned by friends.

I don't want to have a negative attitude, but they just don't seem to accept it, so I went ahead for the examination alone, so out of the five, only one 
person took it. Then after the examination, there was a revision, didn't I, I asked for a signature. I was alone from Garut to Jatinangor (name of regency), alone, sometimes with others. But, from friends who like to play together, it seems like they care less. They seem to be far away, Mrs. (sobs, cries and wipes tears many times) (P9).

The data revealed by the participants described that the peer was very close in the thesis process, both in positive and negative terms.

\section{Supervisor capacity}

Participants share various expressions related to lecturer guidance. Difficulty meeting with supervisors constrained according to the supervisor's schedule, supervisors being replaced in the middle of the thesis journey due to supervisors who must continue studying abroad, between different supervisors making it difficult what to write. These are conditions that occur when guidance. Besides, there are expressions outside of the above.

Then, what kind of mentor is it, Mrs. This week I'm talking like that, so next week even though it's already appropriate. I mean. From the beginning, it told that the mother said it until it was done, but she did it, but just right, the guidance seemed to have collapsed again. So why like that, why like that? I kept saying, Mom, who said this? When did I say, well, I'm being recorded, Mom, for example, guidance. This mother has a recording, like I said. Oh yes. It's hard to share your opinion, even though your opinion has been followed by me (P3).

However, the participants also revealed that their supportive supervisor provided motivation to go to examination immediately, set a time for revision so that it was quickly completed and immediately went to examination (P7, P8, and P9).

\section{Support and pressure from parents}

The role of parents toward children who are completing their thesis was revealed by participants such as parents understand that participants are completing their thesis, parents often calm, motivate, and give attention. Another participant (P9 and P4) revealed that parents often accompany them when they must work on their thesis until late at night and suggest taking a break because they are afraid that the participant will get sick when working on the thesis and forget to take a break.

However, on the other hand, some feel pressured because of their parents. They often ask about the progress of their thesis every time they meet. Participants felt that parents demanded participants graduate immediately, repeatedly asking when their thesis was finished, when to go to examination, and when to graduate.
My parents have been informed, Mrs., so late..., graduation in August will be like that. Well, that's the problem, Mrs., my parents know that I graduated in August, what if I'm late. It's like asking questions before the examination. Right there, the parents of their child's friends have already had an examination, " $X$ when, when is the examination?" Others have updated on Facebook. " $X$, when is the examination?" I like to ask questions like that, ma'am. In a week, I want to ask questions once or twice (P6).

The positive and negative support system is felt when the participant completes the thesis course, this condition may affect the completion of the thesis.

\section{Theme 2: Physical and psychological} problems experienced during the thesis process

Participants revealed various physical, psychological problems to suicidal ideation, during the thesis process.

Physical problems lead to psychosomatic symptoms and infectious diseases

Participants revealed that during the 6-8 months of the thesis process, they experienced health problems such as dizziness, diarrhea, dyspepsia, back pain, and infections.

Well, when it started in December, December, yes, the end of the year. On the $27^{\text {th }}$, I had appendicitis. Had been treated too, in surgery until really January. Then l'm already nervous because l'm scared because this pain is getting worse $(P 3)$.

In addition to infectious diseases, other participants P5, P6, P9, P14, P15, and P16 revealed that they experienced diarrhea until they were hospitalized, their bodies were sick because the distance from their home to campus was far, they were lazy to eat, and have frequent colds.

\section{Physical problems related to immunity and} allergic diseases

Participants shared experiences of allergic diseases that recur during the thesis process, such as sinusitis and epistaxis.

I have sinuses, so sometimes they recur when it's cold, but it can still be controlled by myself. Three days of recovery, I usually call mom, I'll send medicine from Depok later, it's normal after that (P2).

Another participant (P10) said that he had had epistaxis since he was a child. He had not relapsed for a long time but had a recurrence during the thesis process, with a higher amount of bleeding than before. 


\section{Unstable emotions}

All participants shared the experience of emotional changes during the thesis process. The participants felt heavy moments and made them feel down, often cried, angry, feeling afraid, sad, feeling lazy

What's the reaction, Mrs., I'm already fasting, ma'am, by nature, I'm stressed, I want to be angry all the time, by nature, I'm really annoyed that seeing the others have finished, right? He is alone, ma'am, for collecting data, so that's how I feel, Mrs., I want to be angry when completion (P16)

An unstable emotional condition has occurred since entering the first semester of the thesis, feelings of fear arise after listening to experiences from the previous generation. Meanwhile, feelings of sadness, crying, and psychological drop occur when it is difficult to consult with a supervisor, being abandoned by friends, parents asking when to graduate, having difficulty getting data, and the thesis writing process with many improvements or even many improvements changing research topics.

\section{Desire to commit suicide}

The desire to end life was found in one participant. Participants felt the difficulty of passing the thesis when determining the research topic and getting permission for research ethics. The two processes made him late in finishing his thesis compared to his other friends, which caused great stress.

It's just like me, I don't leave the house for a week, I don't go out, it's more... Yes, ma'am, because I'm late. It's like you're always embarrassed, sometimes you ask other people what you mean, it's like sometimes it's a stigma, it's like people are watching, wow it's late, this must be lazy. Even though other problems appear, maybe that can't appear like that. I once, when I committed suicide, I had the urge, maybe there was, but thank God I didn't have time to do it, so I took care of the cat, ma'am, the cat is more sensitive, ma'am, what can I do, when I' sad I get so stressed that it's like, what, If I drink poison, I won't die right away? (laugh). But if, for example... yes if, but if, for example I want a knife (demonstrates the incision on my wrist) but I don't want to get sick, I'm afraid of injections. So... it's like, I'm still thinking about the rope, don't worry, there are still people who love me, God willing. Until well, I once wanted to drink liquid like that but was afraid that I wouldn't immediately drink the poison. the point is that (P15).

Although, in the end, the participants did not commit suicide, this condition is a picture of a serious threat that can occur to every student who feels very heavy stress due to the thesis process.
Theme 3: Learning and expectations for thesis courses

\section{Positive self-efficacy}

The thesis process for students who finish according to the targeted time has an impact on creating a feeling of pride in the work that has been made and confident to become a scholar in their field.

When I graduated, I was also proud of myself, Mrs. He worked on his thesis without the help of others, only the enthusiasm of his friends and the enthusiasm of his parents. This is the only thing that makes you happy. This little happiness makes mama and papa look proud to see their son, They already know there is a problem too. that's what makes him speechless. that's how it is, Mom. It's this little thing that makes parents happy. So proud of yourself. He can finish the thesis... it's hard, Mrs. the thesis... Judging from the close friends who didn't finish it. it's a shame (P14).

Participants also revealed with the thesis that many life lessons can be passed, such as being confident in their abilities, being disciplined in the targets that have been set, using time effectively and efficiently, and believing that everyone has their way of life, so there is no need to worry and worry when different stages of the thesis with friends. Participants submit thesis courses that should still exist.

As for the future, if someone says stop it, there's no need for a script like that, if according to him, it still needs to exist because science is indeed dynamic, so we can't, we only know what, knowledge only ends here. Just like that, so there must be an update for the next update like that ( $P$ 11).

Participants expressed various positive impacts of having thesis courses both for students and for science.

\section{Lack of facilities and improvement of the} guidance system

The participants expressed various obstacles and expectations during the thesis process. Participants conveyed that the previous thesis data were not updated in the library so that some students presented the same research topic as before. Difficulty in assessing credible article and journal by following the topic and purpose.

Hmm... Mrs..., because... I want a fixed title, for example, if you have an older brother at that level, at least you can input it on the faculty website first. Mrs., you don't have to go far on the University website, so it can be coordinated if this title is already available. So, later I want to continue if I want to continue my senior level, I just need to contact my older sister, Mrs. (P 4) In relation to the thesis system and program, 
participants expressed hope for some improvements, especially in the guidance process, especially for lecturers who have a high level of activity. If there is no time to guide students, they should not be responsible to guide thesis students because it will be difficult for both parties, both students and lecturers. Participants also expressed the hope that there will be an introduction to the thesis socialization program and an early warning system for students who have problems with thesis writing so that it will not become a chronic problem, especially until it is too late to solve it.

\section{Discussion}

The results showed that the participants had positive and negative experiences of social support during the thesis process. Participants delivered support from dominant friends. Most of the participants were 22 years old. This age is the age of transition from adolescence to adulthood and is sometimes also called early adulthood. Characteristics of adolescents dependent on peer groups shift to independence [20] so that if it is associated with the results of this study, friends are one of the social supports. Meanwhile, according the previous study showed that International students experienced a loss of social support and caused stress. However, some participants experienced the loss of friends during the thesis process, which made the participants feel alone and lost. Still, they could continue to complete their responsibilities, namely, graduating from the thesis on time.

Previous research has examined the factors that affect the ability of adolescents to control and be on track according to what they aspire to. There are three main factors, including friends/peers [22]. The study results show that the support system components other than friends, namely, parents and supervisors, are conditions that have the potential to improve student fluency in completing the thesis.

This study obtains data on health problems faced during the thesis. The health problems experienced are physical disorders in the form of mild illnesses that can be overcome alone, to diseases that must be assisted by the family and treated in hospital. The physical and psychological problems were expressed by all participants such as tendency for suicide idea. Distress experienced by students because the eyes of the study load have been studied previously [8], [9], [10], [11], [12], [13], however, most of the previous research focused on only one psychological problem, namely, anxiety, the value of which was based on quantitative numbers, not deep, and still general, not specific to thesis courses. Meanwhile, based on the results of this study, the psychological problems experienced were wide, varied, and even life threatening. The results of this study are new information that describes in detail and depth the student's experience in completing the thesis. Although the results of this study cannot be generalized to all students, this information will be very useful for students, parents, educators, and the education system in Indonesia in understanding the physical conditions and mental stress experienced by students during the thesis.

The results showed that the learning process among students. The lessons conveyed are more positive things that can be interpreted after completing thesis courses both personally and in science. Different hopes for the improvement of the guidance process and the completeness of educational support facilities are obtained from this research. The expression of the influence and importance of mentors on specific courses has been studied previously. Research in Australia examining the experiences and expectations of the supervising tutors in the courses taught in blended learning by interviewing 19 students at the undergraduate level, getting the results that the mentors or tutors are very influential on the motivation of students in these courses [23]. The research also found that high scientific capacity and a positive approach when guiding and explaining supervisory material were other points expected by students. Although the focus of this research and the research in Australia is different, both of these studies explore deeply the experiences and expectations of students for lecturers as mentors and tutors. Supervisor is one of the main keys for students in completing thesis courses. Supervisors who provide full support to their students, have high commitment, and are experts in their knowledge will assist students in completing theses in prosperity without feeling distressed both physically and psychologically.

Students' experiences in undergoing thesis courses are shared in depth from this research as nurses whose roles as educators, including educating prospective nurses, which begin with the educational process on campus, will be able to understand and empathize with the condition of students during the thesis. Although this research is limited to nursing students, thesis courses are available in almost all universities and apply to all students studying at the university, both local and international students. Efforts to anticipate various physical and mental problems socialize the process and stages of the thesis, early detection of problems faced by students, guidance, and positive assistance are significant for helping students in the thesis completion process.

The research results on drawing thesis courses are heavy and complex courses for students in Indonesia, thus threatening their physical and mental health. This condition may have implications for international students who will study in Indonesia. Foreign undergraduate students who will study in Indonesia follow the learning system and curriculum in Indonesia, including thesis courses as a determinant for obtaining 
a bachelor's degree. This thesis is only available in Indonesia. Completing the thesis requires language skills, cultural adaptation, and communication skills. Communication skills are needed because students will interact intensely with supervisors. The thesis process for students who come from Indonesia who are not constrained by language and culture is often stress in itself, even causing several suicides. On the other hand, for lecturers in Indonesia to guide international students who will study in Indonesia, lecturers are needed who have the capacity in foreign languages other than Indonesian. Lecturers are also expected to understand student culture so that international students who will attend education in Indonesia can adapt and be able to follow the educational process and complete their thesis or final project well.

\section{Conclusion}

The student experience when completing the thesis is very dynamic, students feel the support of a positive support system, but on the other hand, they feel a loss of support. Various physical and psychological distresses to suicidal ideation threaten students while undergoing the thesis course process. Despite experiencing physical and psychological problems, students can interpret the thesis and take positive lessons and hope that this course will continue to exist. The risk of physical and psychological distress to the threat of suicide is a condition that cannot be ignored in completing a thesis and can threaten local and international students studying in Indonesia. The integrated and comprehensive mentoring service program includes academic and psychological services, which can be one of the efforts to prevent and early detection of distress in students while undergoing thesis.

\section{References}

1. Universitas Padjajaran. Pedoman Penyusunan dan Penulisan Skripsi Program Sarjana Indonesia: Universitas Padjadjaran; 2011. https://doi.org/10.15416/ijcp.2017.6.2.123

2. Gunawati R. Hubungan Antara Efektivitas Komunikasi Mahasiswa-dosen Pembimbing Utama Skripsi Dengan Stres Dalam Menyusun Skripsi Pada Mahasiswa Program Studi Psikologi Fakultas Kedokteran Universitas Diponegoro. Indonesia: Universitas Diponegoro; 2005. https://doi. org/10.24843/jpu.2019.v06.i02.p19

3. Asmawan A. Analisis kesulitan mahasiswa menyelesaikan skripsi. J Pendidik IImu Sosial 2017;26(2):51-7.

4. Suryadi S. Perbedaan Insomnia Pada Mahasiswa Yang Sedang Mengerjakan Skripsi dan Belum Mengerjakan Skripsi.
Indonesia: Universitas Muhammadiyah Surakarta; 2008. https:// doi.org/10.22373/psikoislamedia.v2i1.1822

5. Khalika NN. Depresi Karena Skripsi, Kampus and Dosen Wajib Menolong Mahasiswa. Diakses Pada Tanggal. 2019;17:134.

6. Listanto V, Demak IP. Kecemasan pada mahasiswa angkatan 2010 yang mengerjakan tugas akhir program studi pendidikan dokter FKIK Untad tahun 2010. Med Tadulako J IIm Kedokt Fak Kedokt IImu Kesehat. 2015;2(1):40-9.

7. Aswati $\mathrm{FH}$, Ruhyana R. Hubungan Kecerdasan Emosional Dengan Kemampuan Menyelesaikan Skripsi pada Mahasiswa Program Studi Ilmu Keperawatan STIKES'Aisyiyah Yogyakarta. Indonesia: STIKES'Aisyiyah Yogyakarta; 2014. https://doi. org/10.35842/formil.v6i1.339

8. Hastanto I. Survei: 20 persen mahasiswa di bandung terpikir bunuh diri, kesehatan mental isu Mendesak. Dipost Pada. 2019;14:30.

9. Susanti R. Angka Bunuh Diri Tinggi, Baru 9 Persen Penderita Depresi Dapat Pengobatan Medis. Bandung: KOMPAS; 2019.

10. Anggraeini N. Gambaran tingkat kecemasan pada mahasiswa tingkat tiga D-III Keperawatan dalam menghadapi uji kompetensi di Universitas Pendidikan Indonesia. J Pendidik Keperawatan Indones. 2018;1(2):131-9. https://doi.org/10.17509/jpki. v1i2.9752

11. Anissa LM, Suryani S, Mirwanti R. Tingkat kecemasan mahasiswa keperawatan dalam menghadapi ujian berbasis computer based test. MEDISAINS. 2018;16(2):67-75. https:// doi.org/10.30595/medisains.v16i2.2522

12. Kristianto $\mathrm{H}$, Wihastuti TA, Al-Maris R. Perbedaan tingkat kecemasan mahasiswa dalam menyelesaikan tugas dengan pembagian kelompok berdasarkan metode friendship group dan random group di Fakultas Kedokteran Universitas Brawijaya. J IImu Keperawatan. 2013;1(2):113-8. https://doi.org/10.14421/ jpsi.v6i1.1469

13. Herdiani WS. Pengaruh expressive writing pada kecemasan Menyelesaikan Skripsi. Calyptra. 2013;1(1):1-19.

14. Forbes-Mewett $H$, Sawyer A. International Students and Mental Health. 2016;6(3):661-77. https://doi.org/10.32674/jis.v6i3.348

15. Jackson M, Ray S, Bybell D. International students in the US: Social and psychological adjustment. J Int Stud. 2019;3(1):17-28.

16. Nasirudeen AM, Josephine KW. Acculturative stress among Asian international students in Singapore. J Int Stud. 2019;4(4):363-73. https://doi.org/10.32674/jis.v4i4.455

17. Poyrazli S, Mitchell MA. Mental health problems of US students studying abroad. J Int Stud. 2020;10(1):17-27. https://doi. org/10.32674/jis.v10i1.1014

18. Polit DF, Beck CT. Essentials of Nursing Research: Appraising Evidence Fornursing Practice. United States: Lippincott Williams \& Wilkins; 2014.

19. Wojnar DM, Swanson KM. Phenomenology: An exploration. J Holist Nurs. 2007;25(3):172-80. https://doi. org/10.1177/0898010106295172

20. Hurlock EB. Child Development. $6^{\text {th }}$ ed. New Delhi: Tata McGraw; 1997.

21. Bhochhibhoya A, Dong $Y$, Branscum P. Sources of social support among international college students in the United States. J Int Stud. 2017;7(3):671-86. https://doi.org/10.32674/jis.v7i3.293

22. Fite PJ, Griffith R, Tampke EC, Stone KJ, Srivastava V. Factors associated with perceived containment. J Community Psychol. 2020;48(3):932-44. https://doi.org/10.1002/jcop.22312

23. Koch J, Ramjan LM, Everett B, Maceri A, Bell K, Salamonson Y. Sage on the stage or guide on the side-Undergraduate nursing students experiences and expectations of bioscience tutors in a blended learning curriculum: A qualitative study. J Clin Nurs. 2020;29(5-6):863-71. https://doi.org/10.1111/jocn.15140 